\section{Yi Huang \\ Yong Hai Zhang \\ Ze Pai Chi \\ Ru Huang \\ Hong Huang \\ GuoYuan Liu \\ YuanFeng Zhang \\ HongSheng Yang \\ JiaHua Lin \\ TengHao Yang \\ Si Zhe Cao}

Department of Urology, The Affiliated

Shantou Hospital of Sun Yat-Sen University,

Shantou, China

\title{
The Handling of Oxalate in the Body and the Origin of Oxalate in Calcium Oxalate Stones
}

\section{Keywords}

Hyperoxaluria · Calcium oxalate · SLC26 transporter · SLC4

transporter · Urolithiasis including kidney stone formation. Furthermore, SLC4 and SLC26 exchangers provide new insight into urolithiasis and may be a novel therapeutic target for modification of urinary oxalate excretion.

(c) 2019 S. Karger AG, Basel

\begin{abstract}
Urolithiasis is one of the most common urologic diseases in industrialized societies. More than $80 \%$ of renal stones are composed of calcium oxalate, and small changes in urinary oxalate concentrations affect the risk of stone formation. Elucidation of the source of oxalate and its mechanism of transport is crucial for understanding the etiology of urolithiasis. Sources of oxalate can be both endogenous and exogenous. With regard to oxalate transport, tests were carried out to prove the function of solute-linked carrier 4 (SLC4) and SLC26. The molecular mechanism of urolithiasis caused by SLC4 and SLC26 is still unclear. The growing number of studies on the molecular physiology of SLC4 and SLC26, together with knockout genetic mouse model experiments, suggest that SLC4 and SLC26 may be a contributing element to urolithiasis. This review summarizes recent research on the sources of oxalate and characterization of the oxalate transport ionic exchangers SLC4 and SLC26, with an emphasis on different physiological defects in knockout mouse models
\end{abstract}

\section{Introduction}

Urolithiasis is a common urologic condition with an increasing incidence [1-3]. In Asia, about 1-19.1\% of the population suffers from urolithiasis [4]. The lifetime recurrence risk is $50 \%$, with an estimated time to recurrence of up to 1 year in $10 \%$ of cases, up to 5 years in $35-50 \%$ and up to 10 years in at least $50 \%$ of cases [5]. With lifestyle changes and economic development, the prevalence of urolithiasis has consistently increased in the last few decades. Calcium oxalate $(\mathrm{CaOx})$ is the most common type of stone removed from patients $[6,7]$. More than $70 \%$ of renal stone patients suffer from urolithiasis caused by $\mathrm{CaOx}$ stones; of these, $\mathrm{CaOx}$ dihydrate is the most common crystal in healthy human urine and $\mathrm{CaOx}$ monohydrate is the most common crystal in renal stones $[7,8]$. Supersaturation of urine with $\mathrm{CaOx}$ is a major con- karger@karger.com www.karger.com/uin

(C) 2019 S. Karger AG, Base

Karger!
Yong Hai Zhang 
tributor to $\mathrm{CaOx}$ stone formation [2]. Thus, hyperoxaluria has been well recognized as one of the independent risk factors for stone formation. Oxalate is derived from dietary sources (e.g., plants and plant-derived foods), it can be synthesized by the body, and it is excreted in the urine $[9,10]$. The etiology of hyperoxaluria has different aspects in different people. Frequent consumption of foods containing oxalate and oxalate precursors is thought to contribute to hyperoxaluria in some individuals. A low or suboptimal colonization of oxalate-degrading bacteria in the gastrointestinal tract [11], short bowel or malabsorptive bowel disease [12], and bariatric surgery for obesity [13] are also thought to be contributing factors.

Recently, research has focused on oxalate transport, which is a transcellular process that depends on anion exchangers. Thus, the interest in research on SLC4 and SLC26 has gradually increased. SLC, which belongs to a multifunctional anion exchanger system, is strongly involved in the homeostasis of oxalate [14]. The human erythrocyte band 3 protein (AE1 or SLC4A1) involved in oxalate transport in red blood cells has not been studied in detail, but some papers describe that treatment of red blood cell with different concentrations of $\mathrm{H}_{2}$ DIDS (4,4'-diisothiocyanatostilbene-2,2'-disulfonate) inhibits $\mathrm{Cl}^{-}-\mathrm{Cl}^{-}$and oxalate-oxalate exchange to the same extent, suggesting that SLC4A1 is the major transport pathway for oxalate [15]. Mutations and knockout of SLC4A1 cause distal renal tubular acidosis (dRTA) and spherocytic hemolytic anemia [16]. SCL26A6 is an anion exchanger expressed on the apical membrane in many tissues, including the kidneys and intestines [17-20]. Among its transport activities, SLC26A6 serves as the major pathway for oxalate secretion [21]. Mice lacking SLC26A6 have a defect in intestinal oxalate secretion resulting in an enhanced net absorption of oxalate [22]. SLC26A1, A2, A3, and A7 may also be involved in oxalate exchange [23]. Besides, members of the SLC4 and SLC26 gene families encode $\mathrm{Na}^{+}$-independent $\mathrm{Cl}^{-} / \mathrm{HCO}_{3}{ }^{-}$exchanges which are expressed in many tissues including the kidneys and the gastrointestinal tract. Secretion and reabsorption of acid-base equivalents and of $\mathrm{Cl}^{-}$the $\mathrm{Cl}^{-} /$ $\mathrm{HCO}_{3}{ }^{-}$exchangers regulate the intracellular $\mathrm{pH}$ and $\mathrm{Cl}^{-}$ levels as well as the cell volume [17]. Next, the current knowledge of the mechanisms of SLC4 and SLC26 oxalate exchangers will be discussed in relation to the different etiological types of urolithiasis.

\section{Sources of Oxalate}

Urinary oxalate is derived from both exogenous and endogenous sources that, depending on the dietary in- take, may equally contribute to urinary oxalate excretion [2]. There is new evidence that dietary oxalate may contribute to up to $50-80 \%$ of the oxalate excreted in urine $[2,24]$. Exogenous sources of oxalate are vegetables, fruits, and tea. Foods with a high oxalate content are spinach, rhubarb, tea, spinach, and soya beans. Endogenous sources of oxalate are mainly synthesized by erythrocytes and the liver. The endogenous sources of oxalate include ascorbic acid, protein (through metabolism of the amino acids tyrosine, tryptophan, phenylalanine, and hydroxyproline) and the immediate precursors of oxalate, such as L-glycerate glycollate and glyoxylate [25]. The process of oxalate synthesis in erythrocytes is unknown and the contribution of ascorbate catabolism to urinary oxalate is controversial [26-31]. The liver is the primary source of endogenous oxalate, and glyoxylate is the primary immediate precursor of oxalate [32, 33]. Glyoxylate concentration is mainly regulated by many pathways. Glyoxylate can be metabolized to oxalate by glycolate oxidase or lactate dehydrogenase, and glyoxylate is an important intermediary product in several reactions. Excess glyoxylate will enhance the metabolism of glyoxylate to oxalate, leading to hyperoxaluria. Glyoxylate and alanine can be converted to glycine and pyruvate, respectively, via transamination by alanine/glyoxylate aminotransferase (AGT). AGT is a liver-specific enzyme localized in the peroxisomes that is dependent on the cofactor pyridoxine (vitamin $\mathrm{B}_{6}$ ) for full activity [34]. Glycine is metabolized to seine, and serine is converted to $\mathrm{OH}$-pyruvate which is metabolized glycoaldehyde by glyoxylate reductase/OHpyruvate reductase (GRHPR). Ultimately, glycoaldehyde can be metabolized to glyoxylate via several steps. Another glyoxylate source of pathways is through the breakdown of hydroxyproline [35] via 4-hydroxy-2-oxoglutarate aldolase (HOGA1).

\section{The Etiology of Primary Hyperoxaluria}

Hyperoxaluria is usually divided into the following 2 categories: primary hyperoxaluria $(\mathrm{PH})$ and secondary hyperoxaluria. Depending on the dietary intake, the daily urinary oxalate excretion in healthy individuals ranges between 10 and $40 \mathrm{mg}$ per $24 \mathrm{~h}(0.1-0.45 \mathrm{mmol}$ per $24 \mathrm{~h})$ [36]. Concentrations over $40-45 \mathrm{mg}$ per $24 \mathrm{~h}(0.45-0.5$ mmol per $24 \mathrm{~h}$ ) are considered as indicative of clinical hyperoxaluria [34]. PH is a rare inborn error of glyoxylate metabolism that results in a high oxalate production mainly by the liver $[37,38]$, and $\mathrm{PH}$ is divided into the following 3 classes: PH I, PH II, PHII. PH I, accounting for the majority of all cases (70-80\%) [38], is a peroxisomal disease and the most severe type. It is caused by 
mutations in AGT [39], a peroxisomal enzyme located in the liver; it is a genetic defect disease and it is inherited with an autosomal recessive pattern. Mutation or the absence of AGT resulting in a severe reduction of AGT enzymatic activity in the peroxisome produces more glyoxylate aggregation which is metabolized to oxalate via glycolate oxidase or lactate dehydrogenase, leading to hyperoxaluria. PH II, accounting for around $10 \%$ of $\mathrm{PH}$ cases, is caused by a deficiency of the cytosolic liver enzyme GRHPR [40, 41]. The deficiency or mutation of GRHPR activities in $\mathrm{PH} 2$ patients results in an increase in oxalate and L-glycerate concentrations in urine. The symptoms of hyperoxaluria caused by PH II are slighter than those caused by PH I. Severe hyperoxaluria is the clinical hallmark of these 2 types of $\mathrm{PH}$, with reported values ranging between 88 and $352 \mathrm{mg}$ per $24 \mathrm{~h}$ (1-4 $\mathrm{mmol}$ per $24 \mathrm{~h}$ ) for $\mathrm{PH}$ I and 88 and $176 \mathrm{mg}$ per $24 \mathrm{~h}(1-2$ mmol per $24 \mathrm{~h}$ ) for PH II [42]. PH III, accounting for $10 \%$ of $\mathrm{PH}$ cases, is caused by deficient HOGA 1 , which is a mitochondrial enzyme that cleaves 4-hydroxy-2-oxoglutarate into pyruvate and glyoxylate and the last step of the hydroxyproline degradation pathway [43]. The loss of HOGA1 enzyme activity leading a wide range of oxalate elevations in urine is the characterization of PH III which is becoming more frequent than $\mathrm{PH} 2$ as a cause of $\mathrm{PH}$. All types of $\mathrm{PH}$ causing oxalate metabolism disorders in early childhood to adolescence have a major effect on $\mathrm{CaOx}$ supersaturation, resulting in the formation of nephrocalcinosis/nephrolithiasis. The age of $\mathrm{PH}$ at presentation varies from birth to the sixth decade of life, with a median of 5.5 years [44]. Besides, PH can severely damage renal function and make difficult the diagnosis of $\mathrm{PH}$ based on the lack of significant symptoms and effective inspection methods. In some end-stage renal patients, $\mathrm{CaOx}$ deposited in multiple organs with a renal function decline and increased blood oxalate levels causes systemic oxalosis including metabolic bone disease, anemia, and skin ulcerations.

\section{The Etiology of Secondary Hyperoxaluria}

Secondary hyperoxaluira involves many aspects including: (1) a high-oxalate diet (2) enteric hyperoxaluria, (3) oxalate-degrading microorganisms (4), and SLC4 and SLC26 ionic exchangers.

Secondary hyperoxaluria is the chief risk factor for urolithiasis which can be caused by either an increase in absorption of oxalate in the intestine or intake of a highoxalate diet [45]. For many years it was thought that the dietary source of oxalate contributed only $10-15 \%$ of the daily oxalate excretion. However, it has been reported

Abnormal Hand with Oxalate in a Human Body that dietary oxalate may contribute up to $50-80 \%$ of the oxalate excreted in urine $[2,24]$. Daily dietary oxalate intakes are in the range of $0.05-0.2 \mathrm{~g}$ but may surpass $1 \mathrm{~g}$ if oxalate-rich foods are consumed [46-48]. Some foods, including strawberries, leafy spinach, rhubarb, beets, nuts, wheat bran, chocolate, tea, sorrel, sesame, carambola, almonds, and coffee, have considerably high oxalate concentrations $[47,49]$. Studies have shown that an ample amount of calcium [50], especially when distributed within the food intake, protects against the risk of $\mathrm{CaOx}$ stone formation in patients with stone formation $[51,52]$, apparently owing to the calcium-oxalate interaction and excretion in the gastrointestinal tract. The intake of magnesium is suggested to reduce oxalate absorption and urinary excretion nearly as effectively as calcium by binding oxalate in the gut [53]. Furthermore, hypomagnesiuria is a known risk factor for formation of calcium stones in that magnesium binds to oxalate and reduces the urinary saturation of $\mathrm{CaOx}$ [54]. Protein plays an important role in the process of stone formation [55]. Some amino acids such as L-hydroxyproline are precursors of oxalate which increases the oxalate urine concentration and the relative supersaturation for $\mathrm{CaOx}$ and apparently increases oxalate renal excretion [56].

Oxalate is an endogenous byproduct of amino acid metabolism and it is also absorbed by the stomach, the small bowel, and the colon [57]. Enteric hyperoxaluria is a form of secondary hyperoxaluria caused by disease or resection of the gastrointestinal tract leading to malabsorption syndromes. Small bowel resection or inflammatory bowel disease could interrupt the enterohepatic circulation of bile salts, resulting in bile acid loss and fat malabsorption, which lead to steatorrhea effects on oxalate movement. Enteric hyperoxaluria may have the following 2 main mechanisms: (1) alteration of mucosal oxalate permeability (both dihydroxy bile acid salts and fatty acids increase the permeability of the intestinal mucosa to oxalate; perfusion of rat colonic mucosa with $5 \mathrm{mM}$ sodium deoxycholate markedly increased the colonic permeability to oxalate) [58] and (2) increased luminal ionic oxalate concentrations (in the malabsorption setting with steatorrhea, dietary calcium is bound by the free fatty acids in the intestinal lumen, so less calcium is bound to oxalate; complexation of fatty acids with luminal calcium increases the amount of soluble oxalate that is available for absorption as insoluble $\mathrm{CaOx}$ complexes are no longer formed) [13]. Soluble oxalate is consequently present in relatively high concentrations in the colon and can diffuse passively into blood, where it is filtered and excreted by the kidneys [61]. A number of pa- 
tients with small bowel resection or inflammatory bowel disease have a high incidence of $\mathrm{CaOx}$ stone formation. In bariatric surgery patients it has long been linked to a higher incidence of new-onset nephrolithiasis, with a mean interval from surgery to diagnosis of nephrolithiasis ranging from 1.5 to 3.6 years [59-61]. The risk of nephrolithiasis varies by procedure, being the highest for malabsorptive procedures $(22-28.7 \%)$ [59, 62] which could lead to enteric hyperoxaluria. The association between small bowel resection and increased urinary excretion of oxalate was first recognized in 1970 [63]; subsequently numerous cases have been reported, and many patients undergoing Rouxen-Y gastric bypass for morbid obesity are at risk for hyperoxaluria, nephrolithiasis, and oxalate nephropathy [64]. Enteric hyperoxaluria can cause $\mathrm{CaOx}$ stone disease and, as in $\mathrm{PH}$, the urinary oxalate excretion can be high enough to cause renal damage and eventual end-stage renal disease [65].

It has been recognized for a few decades that intestinal microorganisms can degrade oxalate and reduce the concentration of oxalate in blood and urine. There are many bacteria including Enterococcus faecalis [66], Bifidobacterium infantis [67], and Oxalobacter formigenes [68]. The best well known oxalate-degrading microorganism is $O$. formigenes, a gram-negative anaerobic bacterium isolated from human feces and other animals that is capable of reducing intestinal oxalate absorption. O. formigenes potentially metabolizes the oxalate to formate and $\mathrm{CO}_{2}$ through the formyl-CoA transferase enzyme and the oxalyl-CoA decarboxylase enzyme. Many cases and evidence have confirmed that $O$. formigenes play an important role in degradation of oxalate in the intestinal tract. In a study, the absence of $O$. formigenses in stone formers is associated with an increase in urinary oxalate [69], and stoneformers generally have lower levels of colonization with $O$. formigenses than non-stone formers [70-72]. Besides, bariatric surgery, bowel diseases, and patients with cystic fibrosis could inhibit recolonization of $O$. formigenses in the intestinal lumen, leading to increased absorption of free oxalate and the concentration of oxalate in blood and urine.

\section{SLC4 Transporters}

The SLC4 gene family comprises 3 major clades [73], including $\mathrm{Na}^{+}$-independent electroneutral $\mathrm{Cl}^{-} / \mathrm{HCO}_{3}{ }^{-}$ exchangers (SLC4A1/AE1, SLC4A2/AE2, and SLC4A3/ AE3), $\mathrm{Na}^{+}$-independent $\mathrm{HCO}_{3}{ }^{-}$transporters (electrogenic SLC4A4/NBCel and SLC4A5/NBCe2), electroneutral $\mathrm{Na}^{+} / \mathrm{HCO}_{3}{ }^{-}$cotransports (SLC4A7/NBCn1 and SLC4A10/NBCn2), and $\mathrm{Na}^{+}-2 \mathrm{HCO}_{3}{ }^{-}$exchanger
(SLC4A8/NDCBE) and SLC4A11/BTR1. All SLC4 polypeptides share a common structural pattern of 3 domains. An N-terminal cytoplasmic domain of 400-700 amino acids is followed by a C-terminal polytopic transmembrane domain of $\sim 500$ amino acids and a C-terminal cytoplasmic domain of $\sim 30-100$ amino acids [17]. Besides, SLC4 anion exchangers are involved in anion transport, e.g., plasmalemmal $\mathrm{Cl}^{-} / \mathrm{HCO}_{3}{ }^{-}$exchangers which regulate intracellular $\mathrm{pH}$ and $\mathrm{Cl}^{-}$and cell volume and contribute to transepithelial secretion and reabsorption of acid-base equivalents and of $\mathrm{Cl}^{-}$. In addition, SLC4 exchangers involved in oxalate transport have been reported. SLC4A1, a member of the SLC4 exchangers, has been studied with respect to oxalate transport. We will focus on the structure and function of SLC4A1.

The human SLC4A1/AE1 gene encoding the anion exchanger 1 (AE1/band3) is located on chromosome 17q21$\mathrm{q} 22$, encompassing approximately $20 \mathrm{~kb}$ and consisting of 20 exons separated by 19 introns [74]. The human SLC4A1 encodes both erythroid (eAE1/band3) and kidney (kAE1) isoforms of the AE1 protein by using different promoters and alternative splicing. Band 3 mRNA is transcribed from all exons by its upstream promoter, while kAE1 mRNA is transcribed by the promoter in intron 3 . So, kAE1 mRNA lacks the sequences of exons 1-3 of the eAE1 and sequences shorter than eAE1 which in humans initiates at Met66. Human band 3 protein or eAE1, consisting of a 911-amino acid glycoprotein, comprises 2 distinct structural and functional domains, i.e., a $40-\mathrm{kDa}$ terminal cytoplasmic domain and a $50-\mathrm{kDa} \mathrm{C}$-terminal integral membrane domain. The $\mathrm{N}$-terminal cytosolic domain, from residues $1-360$, interacts with hemoglobin [75], glycolytic enzymes [76], and cytoskeletal proteins including ankyrin [77], protein 4.1 [78], and protein 4.2 [79], while the N-terminal cytoplasmic domain of kAE1 (which is 65 amino acids shorter than that of eAE1) does not bind to ankyrin or glycolytic enzymes and its interacting proteins in the a-intercalated cell remain to be identified. The eAE1 tetramers bind to ankyrin and cytoskeleton proteins. which is critical for maintenance of the biconcave disc shape of red blood cells. The $50-\mathrm{kDa}$ C-terminal in the tergal membrane domain with 12-13 transmembrane spans from residue 361 to residue 882 and mediates $\mathrm{Cl}^{-} / \mathrm{HCO}_{3}{ }^{-}$exchange [80], while the region of mediated oxalate is still unknown. Both eAE1 and kAE1 have a short acidic cytoplasmic C-terminal tail (residues 883-911), containing binding sites for carbonic anhydrase (CA) II [81]. The identical C-terminal tails of AE1 and kAE1 can bind to CAII via an acidic motif (-LDADD-). Bicarbonate $\left(\mathrm{HCO}_{3}^{-}\right)$from the breakdown 
of carbonic acid $\left(\mathrm{H}_{2} \mathrm{CO}_{3}\right)$ generated from hydration of carbon dioxide $\left(\mathrm{CO}_{2}\right)$ by CA II is transported across the cell membrane in exchange for chloride $\left(\mathrm{Cl}^{-}\right)$by AE1 [74]. Red cell eAE1 expressed in the erythrocyte plasma membrane mediates the 1:1 electroneutral exchange of many anions, while $\mathrm{Cl}^{-}$and $\mathrm{HCO}_{3}{ }^{-}$are its major physiological substrates [82]. eAE1 has also been confirmed to mediate oxalate exchange for $\mathrm{Cl}^{-}$. Cousin and Motais [93] showed that various reversibly acting inhibitors have parallel effects on $\mathrm{Cl}^{-}-\mathrm{Cl}^{-}$and oxalate-oxalate exchange, suggesting that red cell oxalate transport is mediate by band 3 , but the characteristics of the transport of oxalate across erythrocyte membrane are still unknown. Jennings and Adame [16] used a low concentration of $\mathrm{H}_{2}$ DIDS (4,4'-diisothiocyanatostilbene-2,2'-disulfonate) with red cells to explore the kinetics of oxalate exchange and $\mathrm{Cl}^{-}$. The results showed that red cell eAE1 mediates $\mathrm{H}^{+}$/oxalate cotransport in electroneutral exchange for $\mathrm{Cl}^{-}$and the apparent $\mathrm{Cl}^{-}$affinity is 2-3 times higher than that of oxalate. Besides, oxalate, at a low extracellular $\mathrm{pH}$, is transported by band 3 nearly as rapidly as $\mathrm{Cl}^{-}$is at neutral $\mathrm{pH}$. To examine the functional difference of erythrocyte band 3 protein in stone formation patients and normal patients, Oehlschläger et al. [84] found that the concentration of erythrocyte band 3 transport protein in stone formation patients is about 2 times higher than that of normal patients, but the plasma oxalate, cellular oxalate, and erythrocyte oxalate fluxes are no different in male stone formation patients versus normal patients. What is more, under normal conditions ( $\mathrm{pH}$ 7.55), the oxalate efflux in stone formation patients is about 2 times higher than that in normal patients in vivo. SLC4A1 may influence cellular oxalate levels and urine oxalate clearance through the exchange of $\mathrm{Cl}^{-} / \mathrm{HCO}_{3}{ }^{-}$and $\mathrm{pH}$ levels.

The SLC4A1 polypeptide is widely expressed in erythrocytes and in type A acid-secreting intercalated cells of the renal collecting duct. In erythrocytes, eAE1 stabilizes the lipid bilayer and its linkage to ankyrin and cytoskeleton proteins to maintain the biconcave disc shape of red blood cells. In the kidney, type A intercalated cells reabsorb $\mathrm{HCO}_{3}{ }^{-}$through apical $\mathrm{H}^{+}$excretion into the urine. Mutations or knockout of the human SLC4A1 gene is divided into erythroid and renal phenotypes and it is linked to a number of human diseases. One group mutation of eAE1 encodes almost entirely asymptomatic polymorphisms encoding blood group antigens recognized by patient antisera in intact erythrocytes [85]. The largest group of mutations or knockout of eAE1 can result in hereditary spherocytosis, a common autosomal dominant hereditary spherocytic anemia with a reduction of osmotic fragility and surface area. Hereditary spherocytosis, involved in many polypeptides such as E40K, G130R, and L707P, can occur from gene nonsense, frameshift, and missense mutations of SLC4A1. Many mutant alleles gene generate unstable mRNA, and the resultant erythrocytes express reduced levels of wild-type eAE1 polypeptide often in the setting of dosage compensation by the wild-type allele. Usually, these patients have a normal renal acidification phenotype, but homozygous SLC4A1 V488M mutation can cause severe hereditary spherocytosis and dRTA [86]. There is a wide variation in clinical phenotypes, ranging from asymptomatic individuals to those with severe hemolytic anemia requiring a blood transfusion [87]. In addition, Southeast Asian ovalocytosis is a morphological red cell abnormality caused by a mutational deletion of $27 \mathrm{bp}$ in exon 11 of SLC4A1 leading to an in-frame 9-amino acid deletion involving Ala400-Ala408 of eAE1 at the junction between the $\mathrm{N}$-terminal domain and the first transmembrane span [88]. The deletion of Ala400-Ala408 of eAE1 impairs insertion of the mutant protein into the membrane [89]. The mutant protein is inactive for anion transport function and decreases red cell formability by forming oligomers. The homozygous mutation is fully lethal in utero in the absence of extraordinary medical intervention [90], while the heterozygous one exhibits inactivity for anion transport and membrane rigidity. The heterozygous SLC4A1 Southeast Asian ovalocytosis mutation does not cause dRTA [91]. However, mutations or knockout of kAE1 can cause dRTA. dRTA is a disease of defective urinary acidification, which is caused by insufficient net acid excretion into the urine by type A-intercalated cells of the kidney. Type A-intercalated cells mediate bicarbonate reabsorption into the blood in exchange for chloride and protons are transported into the urine by apical V-type $\mathrm{H}^{+}$. Patients with dRTA are defective in acid secretion and show an increased urine $\mathrm{pH}$ even after an acid challenge. These patients with dRTA are more susceptible to urolithiasis than normal subjects. The kidney disease dRTA presents in dominant and recessive forms [92]. Dominant mutants of kAE1 like R589Q can form heterodimers with wild-type AE1 and retain the wide-type protein in endoplasmic reticulum [93]. Homozygous kAE1 mutants, such as s773p [94], causing recessive renal tubular acidosis, impair protein trafficking to the cell surface. Compound heterozygote recessive mutants such as G701D and A858D of kAE1 can form heterodimers that are predominantly retained in the endoplasmic reticulum [95], while heterodimers with the wild-type protein can traffic to the plasma membrane in transfected human em- 
bryonic kidneys. Recently, the developed high-resolution melting method is efficient and reproducible for detection of SLC4A1 mutations and polymorphisms [96], making the diagnosis of dRTA caused by SLC4A1 easily.

\section{SLC26 Transporters}

SLC26 isoforms constitute a conserved family of anion transporters with 10 distinct members [97], including SLC26A1, SLC26A2, SLC26A3, SLC26A4, SLC26A5, SLC26A6, SLC26A7, SLC26A8, SLC26A9, and SLC26A11. SLC26A10 is a pseudogene and therefore not involved. SLC26 polypeptides are characterized by $\mathrm{N}$-terminal cytoplasmic domains, 10-14 hydrophobic transmembrane spans, and C-terminal cytoplasmic STAS domains and appear to be homo-oligomeric [24]. The SLC26 gene family, except for SLC26A5/prestin, encodes multifunctional anion exchangers and channels transporting amounts of substrates, including $\mathrm{Cl}^{-}$, $\mathrm{HCO}_{3}{ }^{-}$, oxalate, sulfate, and formate. Several SLC26 family members can specifically function as $\mathrm{Cl}^{-} / \mathrm{HCO}_{3}{ }^{-}$ , including SLC26A3, SLC26A4, SLC26A6, SLC26A7, SLC26A9, and SLC26A9. SLC26 family members, including SLC26A1, SLC26A2, SLC26A3, SLC26A6, and SLC26A7, may be involved in oxalate transport.

SLC26A1/Sat1, the first member of the SLC26 family, was cloned from a rat liver [98] and is localized to the basolateral plasma membrane of hepatocytes and proximal tubular cells of the kidney (segments S1, S2, and S3), respectively $[99,100]$. The human SLC26A1/Sat1 gene is mapped to chromosome $4 p 16.3$ [101]. SLC26A1/Sat1 is an anion exchanger for sulfate and bicarbonate that is capable of mediating oxalate transport and the affinity for oxalate is lower than for counter anions. Some studies in rats and mice have reported that gender differences in SLC26A1/Sat 1 expression, with a male-dominant expression, may explain the morbidity of oxalate urolithiasis in males and females. A study of SLC26A1/Sat1 in rats indicated that male rats, in comparison to female rats, exhibited higher plasma oxalate levels, a higher renal expression of SLC26A1/Sat1, and a higher excretion of oxalate in urine [102]. In rats treated with ethylene glycol, female rats showed awake oxalemia and an absence of oxaluria compared to male rats which showed hyperoxalemia, hyperoxaluria, and oxalate urolithiasis by elevating protein expression of the hepatic and renal oxalate transporter SCL26A1/Sat1 [103]. In humans, the incidence of urolithiasis is 2- to 3 -fold higher in middle aged male patients (age 30-59 years) but similar in both genders in young and old patients [104]. These studies indicated that sex hormones may be a contributor to gender-dependent devel- opment of oxalate nephrolithiasis in humans and rats. Research in SLC26A1/Sat1-null mice has demonstrated that Sat1 plays an important role in homeostasis of both sulfate and oxalate [105]. Slc26A1/Sat1-null mice have a hyperoxalemia:plasma oxalate level that is higher in Sat1null mice than in wild-type Sat1 mice, and Sat1-null mice exhibits hyperoxalemia, hyperoxaluria, and calcium urolithiasis. The loss of SLC26A1/Sat1 leads not only to urinary stone formation and drug-induced hepatotoxicity but also to hyposulfatemia, hypersulfaturia, and enhanced hepatotoxicity in SLC26A1/Sat1-null mice [106]. Recent research has indicated that mutations SLC26A1 could cause a recessive mendelian form of nephrolithiasis [107].

SLC26A2/diastrophic dysplasia sulfate transporter (DTDST) was first identified by positional cloning as the gene underlying autosomal recessive diastrophic dysplasia [108]. In humans, SLC26A2/DTDST comprises 3 exons and encodes a 739-amino acid protein. SLC26A2/ DTDST is a DTDST and it is located at the apical membrane of the rat small intestine, the rat proximal tubule, the human colon, and prominently in chondrocytes. SLC26A2/DSDST can mediate $\mathrm{SO}_{4}{ }^{2-}, \mathrm{Cl}^{-}, \mathrm{HCO}_{3}{ }^{-}$, and oxalate transport [109]. Exchange $\mathrm{SO}_{4}{ }^{2-}$ of SLC26A2/ DSDST is critical for cartilage development and function [110], and the function of SLC26A2/DSDST in chondrocytes cannot be compensated for by any of the other SLC26 $\mathrm{SO}_{4}{ }^{2-}$ transporters, such as the ubiquitous SCL26A1 and SLC26A6 or SLC26A3 [111, 118]. Mutations in SLC26A2/ DSDST are associated with diastrophic dysplasia [112]. The features of the disease are generally attributed to a lack of $\mathrm{SO}_{4}{ }^{2-}$ transport which is needed for sulfation of extracellular matrix proteins, and knockdown and overexpression of SLC26A2/DSDST have revealed an essential role of SLC26A2/DSDST in chondrocyte differentiation and maturation [113]. Some results have indicated that the properties of oxalate transport closely resemble those of $\mathrm{SO}_{4}{ }^{2-}$ transport, but the oxalate transport rate is $\sim 50 \%$ slower than the $\mathrm{SO}_{4}{ }^{2-}$ transport rate [114]. Besides, SLC26A2 is not likely to play a major role in oxalate metabolism in the colon or the kidney [114]; neither hyperoxaluria nor lithiasis has been noted among mice or patients with SLC26A2 chondrodysplasias.

SLC26A3/DRA (downregulated in adenoma) was first identified as a candidate tumor suppressor gene [115]. SLC26A3/DRA is expressed on the apical membrane of enterocytes of humans and it mediates $\mathrm{Cl}^{-}, \mathrm{HCO}_{3}{ }^{-}, \mathrm{OH}^{-}$, and oxalate transport. Recent research has demonstrated that the deletion of SLC26A3/DRA in knockout mice results in a significant reduction of urinary oxalate excretion and serum oxalate concentrations [116], suggesting 
that SLC26A3/DRA has a critical role in oxalate transport in enterocytes by reducing the mucosa-to-serosa oxalate transport in the ileum and colon. Human diseases are associated with mutations of SLC26A3/DRA, such as congenital chloride-losing diarrhea, which is characterized by watery stool with an excess of chloride and metabolic alkalosis [117]. Mice lacking SLC26A3/DRA show a reduced $\mathrm{Cl}^{-} / \mathrm{HCO}_{3}{ }^{-}$transport ability in the colon epithelium that leads to acidic diarrhea with chloride content and volume depletion and growth retardation [118].

SLC26A6/PAT1 was first cloned by homology from humans [19], encompassing 21 coding exons and about $10 \mathrm{~kb}$ of genomic DNA. The expression of the human SLC26A6/PAT1 gene on human chromosome 3p21 [18] is widespread, with considerable transcripts in several epithelial and nonepithelial tissues [119], including the intestine, the kidney proximal tubule, and the heart. SLC26A6/PAT1 is a multifunction mode of anion exchange involving $\mathrm{Cl}^{-}, \mathrm{HCO}_{3}{ }^{-}$, sulfate, hydroxyl, and oxalate. The mouse SLC26A6-mediated $\mathrm{Cl}^{-}$/formate exchange is electroneutral [120], while $\mathrm{Cl}^{-}$/oxalate is electronic [121]. SLC26A6/PAT1 is expressed on the apical membrane in many gastrointestinal tissues, including the pancreas and the small intestine [19]. SLC26A6/PAT1 is expressed at high levels in the small intestine (at equivalent levels in the duodenum and jejunum and at lower levels in the ileum), with far lower levels of expression in the large intestine [21]. Recently, it was observed that SLC26A6-knockout mice have a reduced (50-75\%) enteric secretion of oxalate and an increased net amount of oxalate absorbed in the gastrointestinal tract rather than a net proximal tubular secretion of oxalate, elevating plasma oxalate and causing hyperoxaluria. Moreover, SLC26A6 knockout mice present urinary oxalate calcium stones while wild-type mice present no birefringent deposits in the kidneys. This research confirms the fact that SLC26A6/PAT1 is a major oxalate-secreting transporter and may be a new target for curing $\mathrm{CaOx}$ stones in the gastrointestinal tract. Human SLC26A6/PAT1 has a lower affinity for extracellular $\mathrm{Cl}^{-}$, and $\mathrm{Cl}^{-}$-oxalate exchange appears to be electroneutral, suggesting that human intestinal oxalate secretion is less efficient relative to SLC26A6-null mice [121].

SLC26A7 was cloned on the basis of homology to other SLC26 isoforms [122]. In humans, SLC26A7 maps to chromosome 8 and encodes a 656-amino acid protein. SLC26A7 has been reported to exhibit $\mathrm{Cl}^{-}, \mathrm{HCO}_{3}$, and oxalate exchange activity. SLC26A7 is localized to the basolateral membrane of the stomach's parietal cells and the basolateral membrane of renal collecting duct type A in- tercalated cells [123]. The mechanism of oxalate transport of SLC26A7 is unknown, but the transport may be involved in the deposition of $\mathrm{CaOx}$ crystals in the lumens of the medullary collecting ducts in hyperoxaluric rats [124]. In addition, one study showed that oxalate transport at the papillary epithelial membrane can be involved in deposition of $\mathrm{CaOx}$ crystals onto Randall's plaques [125]. SLC26A7-null mouse was remarkable for dRTA and gastric hypochlorhydria [126] because of a reduced basolateral $\mathrm{Cl}^{-}-\mathrm{HCO}_{3}{ }^{-}$anion exchange activity.

\section{Conclusion}

Oxalate transport in the human body, including the intestine, red blood cells, and kidneys) is complicated. There are many factors that could change the normal manner of oxalate transport, contributing to elevate oxalate concentration of blood and urine and increasing the incidence rate of $\mathrm{CaOx}$ stone formation. However, it is important to be aware that SLC26 and SLC4 anion exchange transporters play an indispensable role in maintaining oxalate homeostasis. In the future, SLC26 and SLC4 anion exchange transporters may become new targets to cure $\mathrm{CaOx}$ stones. Our next research will elaborate on the relationship of $\mathrm{CaOx}$ stones and anion exchange transporters.

\section{Acknowledgment}

Thanks go to Prof. YuChen Liu for language editing.

\section{Disclosure Statement}

The authors declare no conflict of interests.

\section{Funding Sources}

None.

\section{Author Contributions}

Yi Huang, Ze Pai Chi, and Ru Huang are first authors. Yong Hai Zhang is the corresponding author. Yi Huang drafted this paper. Ze Pai Chi and Ru Huang contributed to revision of this paper for important content. Yong Hai Zhang revised and approved the final version of this paper. All of the authors read and approved the final version of this paper. 


\section{References}

1 Li YH, Zhang J, Liu HY. Curcumin ameliorates glyoxylate-induced calcium oxalate deposition and renal injuries in mice. Phytomedicine. 2019 Aug;61:152861.

2 Holmes RP, Goodman HO, Assimos DG. Contribution of dietary oxalate to urinary oxalate excretion. Kidney Int. 2001 Jan;59(1): 270-6.

3 Ortiz YV, Arestin CC, Medina PG, Torres PP. Urolithiasis: population analysis and composition. Clin Chim Acta. 2019;493:S460-92.

4 Liu Y, Chen YT. Epidemiology of urolithiasis in Asia. Asian J Urol. 2018 Oct;5(4):205-14.

5 Penniston KL, McLaren ID, Greenlee RT, Nakada SY. Urolithiasis in a rural Wisconsin population from 1992 to 2008: narrowing of the male-to-female ratio. J Urol. 2011 May; 185(5):1731-6.

6 Tsujihata M. Mechanism of calcium oxalate renal stone formation and renal tubular cell injury. Int J Urol. $2008 \mathrm{Feb} ; 15(2): 115-20$.

7 Ivanovski O, Drüeke TB. A new era in the treatment of calcium oxalate stones? Kidney Int. 2013 Jun;83(6):998-1000.

8 Schubert G. Stone analysis. Urol Res. 2006 Apr;34(2):146-50.

9 Holmes RP, Assimos DG. The impact of dietary oxalate on kidney stone formation. Urol Res. 2004 Oct;32(5):311-6.

10 Holmes RP, Ambrosius WT, Assimos DG Dietary oxalate loads and renal oxalate handling. J Urol. 2005 Sep;174(3):943-7.

11 Hatch M, Freel RW. The roles and mechanisms of intestinal oxalate transport in oxalate homeostasis. Semin Nephrol. 2008 Mar; 28(2):143-51.

12 Worcester EM. Stones from bowel disease. Endocrinol Metab Clin North Am. 2002 Dec: 31(4):979-99.

13 Lieske JC, Kumar R, Collazo-Clavell ML. Nephrolithiasis after bariatric surgery for obesity. Semin Nephrol. 2008 Mar;28(2):16373.

14 Kleta R. A key stone cop regulates oxalate homeostasis. Nat Genet. 2006 Apr;38(4):403-4.

15 Jennings ML, Adame MF. Characterization of oxalate transport by the human erythrocyte band 3 protein. J Gen Physiol. 1996 Jan; 107(1):145-59.

16 Alper SL. Molecular physiology of SLC4 anion exchangers. Exp Physiol. 2006 Jan;91(1): 153-61.

17 Waldegger S, Moschen I, Ramirez A, Smith RJ, Ayadi H, Lang F, et al. Cloning and characterization of SLC26A6, a novel member of the solute carrier 26 gene family. Genomics. 2001 Feb;72(1):43-50.

18 Lohi H, Kujala M, Kerkelä E, Saarialho-Kere U, Kestilä M, Kere J. Mapping of five new putative anion transporter genes in human and characterization of SLC26A6, a candidate gene for pancreatic anion exchanger. Genomics. 2000 Nov;70(1):102-12.
19 Knauf F, Yang CL, Thomson RB, Mentone SA, Giebisch G, Aronson PS. Identification of a chloride-formate exchanger expressed on the brush border membrane of renal proximal tubule cells. Proc Natl Acad Sci USA. 2001 Jul; 98(16):9425-30.

20 Wang Z, Petrovic S, Mann E, Soleimani M. Identification of an apical $\mathrm{Cl}(-) / \mathrm{HCO} 3(-)$ exchanger in the small intestine. Am J Physiol Gastrointest Liver Physiol. 2002 Mar: 282(3):G573-9.

21 Mukaibo T, Munemasa T, George AT, Tran DT, Gao X, Herche JL, et al. The apical anion exchanger Slc26a6 promotes oxalate secretion by murine submandibular gland acinar cells. J Biol Chem. 2018 Apr;293(17):6259-68.

22 Jiang Z, Asplin JR, Evan AP, Rajendran VM, Velazquez H, Nottoli TP, et al. Calcium oxalate urolithiasis in mice lacking anion transporter Slc26a6. Nat Genet. 2006 Apr;38(4): 474-8.

23 Alper SL, Sharma AK. The SLC26 gene family of anion transporters and channels. Mol Aspects Med. 2013 Apr-Jun;34(2-3):494-515.

24 Assimos DG, Holmes RP. Role of diet in the therapy of urolithiasis. Urol Clin North Am. 2000 May;27(2):255-68

25 Fargue S, Knight J, Holmes RP, Rumsby G, Danpure CJ. Effects of alanine:glyoxylate aminotransferase variants and pyridoxine sensitivity on oxalate metabolism in a cellbased cytotoxicity assay. Biochim Biophys Acta. 2016 Jun;1862(6): 1055-62.

26 Chai W, Liebman M, Kynast-Gales S, Massey L. Oxalate absorption and endogenous oxalate synthesis from ascorbate in calcium oxalate stone formers and non-stone formers. Am J Kidney Dis. 2004 Dec;44(6):1060-9.

27 Massey LK, Liebman M, Kynast-Gales SA. Ascorbate increases human oxaluria and kidney stone risk. J Nutr. 2005 Jul;135(7):1673-7.

28 Taylor EN, Stampfer MJ, Curhan GC. Dietary factors and the risk of incident kidney stones in men: new insights after 14 years of followup. J Am Soc Nephrol. 2004 Dec;15(12): 3225-32.

29 Auer BL, Auer D, Rodgers AL. The effect of ascorbic acid ingestion on the biochemical and physicochemical risk factors associated with calcium oxalate kidney stone formation. Clin Chem Lab Med. 1998 Mar;36(3):143-7.

30 Hatch M, Mulgrew S, Bourke E, Keogh B, Costello J. Effect of megadoses of ascorbic acid on serum and urinary oxalate. Eur Urol. 1980;6(3):166-9.

31 Auer BL, Auer D, Rodgers AL. Relative hyperoxaluria, crystalluria and haematuria after megadose ingestion of vitamin C. Eur J Clin Invest. 1998 Sep;28(9):695-700.

32 Baker PR, Cramer SD, Kennedy M, Assimos DG, Holmes RP. Glycolate and glyoxylate metabolism in HepG2 cells. Am J Physiol Cell Physiol. 2004 Nov;287(5):C1359-65.
33 Behnam JT, Williams EL, Brink S, Rumsby G Danpure CJ. Reconstruction of human hepatocyte glyoxylate metabolic pathways in stably transformed Chinese-hamster ovary cells. Biochem J. 2006 Mar;394(Pt 2):409-16.

34 Marengo SR, Romani AM. Oxalate in renal stone disease: the terminal metabolite that just won't go away. Nat Clin Pract Nephrol. 2008 Jul;4(7):368-77.

35 Knight J, Jiang J, Assimos DG, Holmes RP. Hydroxyproline ingestion and urinary oxalate and glycolate excretion. Kidney Int. 2006 Dec;70(11):1929-34

36 Robijn S, Hoppe B, Vervaet BA, D’Haese PC, Verhulst A. Hyperoxaluria: a gut-kidney axis? Kidney Int. 2011 Dec;80(11):1146-58

37 Hoppe B, Beck BB, Milliner DS. The primary hyperoxalurias. Kidney Int. 2009 Jun;75(12): 1264-71.

38 Danpure CJ. Molecular etiology of primary hyperoxaluria type 1: new directions for treatment. Am J Nephrol. 2005 May-Jun;25(3): 303-10.

39 Wood DK, Holmes RP, Erbe D. Reduction in urinary oxalate excretion in mouse models of primary hyperoxaluria by RNA interference inhibition of liver lactate dehydrogenase activity. Biochim Biophys Acta Mol Basis Dis. 2019 Sep 1;1865(9):2203-09.

40 Bobrowski AE, Langman CB. The primary hyperoxalurias. Semin Nephrol. 2008 Mar; 28(2):152-62.

41 Leumann E, Hoppe B. The primary hyperoxalurias. J Am Soc Nephrol. 2001 Sep;12(9): 1986-93.

42 De Broe ME, Porter GA. Chapter 32: Oxalate. In: De Broe ME, Porter GA, editors. Clinical Nephrotoxins: Renal Injury from Drugs and Chemicals. 3rd ed. New York, NY, USA Springer; 2008. pp. 749-56.

43 Phang JM, Hu CA, Valle D. Disorders in proline and hydroxyproline metabolism. In: Scriver CR, Beaudet AL, Sly WS, Valle D, Childs B, editors. The metabolic and molecular bases of inherited disease. 8th ed. New York: McGraw-Hill; 2001. p. 1821-38.

44 Cochat P, Rumsby G. Primary hyperoxaluria. N Engl J Med. 2013 Aug;369(7):649-58.

45 Siener R, Bade DJ, Hesse A, Hoppe B. Dietary hyperoxaluria is not reduced by treatment with Lactic acid bacteria, J Transl Med. 2013; 11:306e313.

46 Siener R, Schade N, Nicolay C. The efficacy of dietary intervention on urinary risk factors for stone formation in recurrent calcium oxalate stone patients. J Urol. 2005; 173: $1601 \mathrm{e} 1605$.

47 Siener R, Honow R, Voss S, Seidler A, Hesse A. Oxalate content of cereals and cereal products, J Agric Food Chem. 2006;54:3008e3011.

48 Taylor EN, Curhan GC. Oxalate intake and the risk for nephrolithiasis, J Am Soc Nephrol. 2007;18:2198e2204. 
49 Duncan SH, Richardson AJ, Kaul P, Holmes RP, Allisonand MJ, Stewart CS. O. Formigenes and its potential role in human health. Appl Environ Microbiol. 2002;68:3841e3847.

50 Borghi L, Schianchi T, Meschi T, Guerra A, Allegri F, Maggiore U, et al. Comparison of two diets for the prevention of recurrent stones in idiopathic hypercalciuria. N Engl J Med. 2002 Jan;346(2):77-84.

51 Domrongkitchaiporn S, Sopassathit W, Stitchantrakul W, Prapaipanich S, Ingsathit A, Rajatanavin R. Schedule of taking calcium supplement and the risk of nephrolithiasis. Kidney Int. 2004 May;65(5):1835-41.

52 de O G Mendonça C, Martini LA, Baxmann AC, Nishiura JL, Cuppari L, Sigulem DM, et al. Effects of an oxalate load on urinary oxalate excretion in calcium stone formers. J Ren Nutr. 2003 Jan;13(1):39-46.

53 Liebman M, Costa G. Effects of calcium and magnesium on urinary oxalate excretion after oxalate loads. J Urol. 2000 May;163(5): 1565-9.

54 Hornberger B, Bollner MR. Kidney stones. Physician Assist Clin. 2018;3(1):37-54.

55 Canales BK, Anderson L, Higgins L, Slaton J, Roberts KP, Liu N, et al. Second prize: comprehensive proteomic analysis of human calcium oxalate monohydrate kidney stone matrix. J Endourol. 2008 Jun;22(6):1161-7.

56 Mendonca FS, Pedreira RS. Hydroxyproline and starch consumption and urinary supersaturation with calcium oxalate in cats. Anim Feed Sci Technol. 2018;18:S0377.

57 Nazzal L, Puri S, Goldfarb DS. Enteric hyperoxaluria: an important cause of end-stage kidney disease, Nephrol Dial Transpl. 2016; 31: $375 \mathrm{e} 382$

58 Dobbins JW, Binder HJ. Effect of bile salts and fatty acids on the colonic absorption of oxalate. Gastroenterology. 1976 Jun;70(6):1096100.

59 Sinha MK, Collazo-Clavell ML, Rule A, Milliner DS. Hyperoxaluric nephrolithiasis is a complication of Roux-en-Y gastric bypass surgery. Kidney Int. 2007;72:100e107,

60 Asplin JR, Coe FL. Hyperoxaluria in kidney stone formers treated with modern bariatric surgery. J Urol. 2007;177:565e569

61 Durrani O, Morrisroe S, Jackman S, Averch T. Analysis of stone disease in morbidly obese patients undergoing gastric bypass surgery. J Endourol. 2006;20:749e752.

62 Requarth JA, Burchard KW, Colacchio TA, Stukel TA, Mott LA, Greenberg ER, et al. Long-term morbidity following jejunoileal bypass: the continuing potential need for surgical reversal. Arch Surg. 1995 Mar;130(3): 318-25.

63 Kaye MC, Streem SB, Hall PM. Enteric hyperoxaluria associated with external biliary drainage. J Urol. 1994 Feb;151(2):396-7.

64 Duffey BG, Alanee S. Hyperoxaluria is a longterm consequence of Roux-en-Y gastric bypass: a 2-year prospective longitudinal study. Amsterdam: Elsevier;2010. p. 211
65 Mole DR, Tomson CR, Mortensen N, Winearls CG. Renal complications of jejunoileal bypass for obesity. QJM. $2001 \mathrm{Feb}$;94(2): 69-77.

66 Hokama S, Honma Y, Toma C, Ogawa Y. Oxalate-degrading Enterococcus faecalis. Microbiol Immunol. 2000;44(4):235-40.

67 Campieri C, Campieri M, Bertuzzi V, Swennen E, Matteuzzi D, Stefoni S, et al. Reduction of oxaluria after an oral course of lactic acid bacteria at high concentration. Kidney Int. 2001 Sep;60(3):1097-105.

68 Turkmen K, Erdur FM. The relationship between colonization of Oxalobacter formigenes serum oxalic acid and endothelial dysfunction in hemodialysis patients: from impaired colon to impaired endothelium. Med Hypotheses. 2015 Mar;84(3):273-5.

69 Kwak C, Kim HK, Kim EC, Choi MS, Kim $\mathrm{HH}$. Urinary oxalate levels and the enteric bacterium Oxalobacter formigenes in patients with calcium oxalate urolithiasis. Eur Urol. 2003 Oct;44(4):475-81.

70 Kumar R, Mukherjee M, Bhandari M, Kumar A, Sidhu H, Mittal RD. Role of Oxalobacter formigenes in calcium oxalate stone disease: a study from North India. Eur Urol. 2002 Mar; 41(3):318-22.

71 Troxel SA, Sidhu H, Kaul P, Low RK. Intestinal Oxalobacter formigenes colonization in calcium oxalate stone formers and its relation to urinary oxalate. J Endourol. 2003 Apr; 17(3):173-6.

72 Mikami K, Akakura K, Takei K, Ueda T, Mizoguchi K, Noda M, et al. Association of absence of intestinal oxalate degrading bacteria with urinary calcium oxalate stone formation. Int J Urol. 2003 Jun;10(6):293-6.

73 Alper SL. Genetic diseases of acid-base transporters. Annu Rev Physiol. 2002;64(1):899923.

74 Yenchitsomanus PT, Kittanakom S, Rungroj $\mathrm{N}$, Cordat E, Reithmeier RA. Molecular mechanisms of autosomal dominant and recessive distal renal tubular acidosis caused by SLC4A1 (AE1) mutations. J Mol Genet Med. 2005 Nov;1(2):49-62.

75 Basu A, Chakrabarti A. Hemoglobin interacting proteins and implications of spectrin hemoglobin interaction. J Proteomics. 2015 Oct; 128:469-75.

$76 \mathrm{Chu} \mathrm{H}$, Low PS. Mapping of glycolytic enzyme-binding sites on human erythrocyte band 3. Biochem J. 2006 Nov;400(1):143-51.

77 Chang SH, Low PS. Identification of a critical ankyrin-binding loop on the cytoplasmic domain of erythrocyte membrane band 3 by crystal structure analysis and site-directed mutagenesis. J Biol Chem. 2003 Feb;278(9): 6879-84.

78 Lombardo CR, Willardson BM, Low PS. Localization of the protein 4.1-binding site on the cytoplasmic domain of erythrocyte membrane band 3. J Biol Chem. 1992 May;267(14): 9540-6.
79 Low PS. Structure and function of the cytoplasmic domain of band 3: center of erythrocyte membrane-peripheral protein interactions. Biochim Biophys Acta. 1986 Sep; 864(2):145-67.

80 Groves JD, Tanner MJ. Topology studies with biosynthetic fragments identify interacting transmembrane regions of the human redcell anion exchanger (band 3; AE1). Biochem J. 1999 Dec;344(Pt 3):687-97.

81 Vince JW, Reithmeier RA. Carbonic anhydrase II binds to the carboxyl terminus of human band 3, the erythrocyte $\mathrm{C} 1-/ \mathrm{HCO} 3-\mathrm{ex}-$ changer. J Biol Chem. 1998 Oct;273(43): 28430-7.

82 Alper SL. Molecular physiology and genetics of $\mathrm{Na}$--independent SLC4 anion exchangers. J Exp Biol 2009;212:1672-83.

83 Cousin JL, Motais R. Inhibition of anion permeability by amphiphilic compounds in human red cell: evidence for an interaction of niflumic acid with the band 3 protein. J Membr Biol. 1979 Apr;46(2):125-53.

84 Oehlschläger S, Fuessel S, Meye A, Herrmann J, Lotzkat U, Froehner M, et al. Importance of erythrocyte band III anion transporter (SLC4A1) on oxalate clearance of calcium oxalate monohydrate stone-formering patients vs. normal controls. Urology. 2011 Jan;77(1): 250.e1-5.

85 Alper SL. Molecular physiology of SLC4 anion exchangers. Exp Physiol. 2006;91:153-61.

86 Ribeiro ML, Alloisio N, Almeida H, Gomes C, Texier P, Lemos C, et al. Severe hereditary spherocytosis and distal renal tubular acidosis associated with the total absence of band 3 . Blood. 2000 Aug;96(4):1602-4.

87 Trompeter S, King MJ. Hereditary spherocytosis. Paediatr Child Health. 2019;8:368-79.

88 Jarolim P, Palek J, Amato D, Hassan K, Sapak P, Nurse GT, et al. Deletion in erythrocyte band 3 gene in malaria-resistant Southeast Asian ovalocytosis. Proc Natl Acad Sci USA. 1991 Dec;88(24):11022-6.

89 Cheung JC, Li J, Reithmeier RA. Topology of transmembrane segments 1-4 in the human chloride/bicarbonate anion exchanger 1 (AE1) by scanning $\mathrm{N}$-glycosylation mutagenesis. Biochem J. 2005 Aug;390(Pt 1):137-44.

90 Picard V, Proust A, Eveillard M, Flatt JF, Couec ML, Caillaux G, et al. Homozygous Southeast Asian ovalocytosis is a severe dyserythropoietic anemia associated with distal renal tubular acidosis. Blood. 2014 Mar; 123(12):1963-5.

91 Bruce LJ, Wrong O, Toye AM, Young MT, Ogle G, Ismail Z, et al. Band 3 mutations, renal tubular acidosis and South-East Asian ovalocytosis in Malaysia and Papua New Guinea: loss of up to $95 \%$ band 3 transport in red cells. Biochem J. 2000 Aug;350(Pt 1):41-51.

92 Cordat E, Reithmeier RA. Expression and interaction of two compound heterozygous distal renal tubular acidosis mutants of kidney anion exchanger 1 in epithelial cells. Am J Physiol Renal Physiol. 2006 Dec;291(6): F1354-61. 
93 Quilty JA, Li J, Reithmeier RA. Impaired trafficking of distal renal tubular acidosis mutants of the human kidney anion exchanger kAE1. Am J Physiol Renal Physiol. 2002 May;282(5):F810-20.

94 Kittanakom S, Cordat E, Reithmeier RA. Dominant-negative effect of Southeast Asian ovalocytosis anion exchanger 1 in compound heterozygous distal renal tubular acidosis. Biochem J. 2008 Mar;410(2):27181

95 Ungsupravate D, Sawasdee N, Khositseth S, Udomchaiprasertkul W, Khoprasert S, Li J, et al. Impaired trafficking and intracellular retention of mutant kidney anion exchanger 1 proteins (G701D and A858D) associated with distal renal tubular acidosis. Mol Membr Biol. 2010 Apr;27(2-3):92-103.

96 Nettuwakul C, Sawasdee N, Yenchitsomanus PT. Rapid detection of solute carrier family 4, member 1 (SLC4A1) mutations and polymorphisms by high-resolution melting analysis. Clin Biochem. 2010 Mar; 43(4-5):497-504.

97 Soleimani M. SLC26 Cl-/HCO3 - exchangers in the kidney: roles in health and disease. Kidney Int. 2013;2013(4):138

98 Bissig M, Hagenbuch B, Stieger B, Koller T, Meier PJ. Functional expression cloning of the canalicular sulfate transport system of rat hepatocytes. J Biol Chem. 1994 Jan; 269(4):3017-21.

99 Karniski LP, Lötscher M, Fucentese M, Hilfiker H, Biber J, Murer H. Immunolocalization of sat-1 sulfate/oxalate/bicarbonate anion exchanger in the rat kidney. Am J Physiol. 1998 Jul;275(1):F79-87.

100 Quondamatteo F, Krick W, Hagos Y, Krüger MH, Neubauer-Saile K, Herken R, et al. Localization of the sulfate/anion exchanger in the rat liver. Am J Physiol Gastrointest Liver Physiol. 2006 May;290(5):G1075-81.

101 Regeer RR, Lee A, Markovich D. Characterization of the human sulfate anion transporter (hsat-1) protein and gene (SAT1; SLC26A1). DNA Cell Biol. 2003 Feb;22 (2):107-17.

102 Brzica H, Breljak D, Krick W, Lovrić M, Burckhardt G, Burckhardt BC, et al. The liver and kidney expression of sulfate anion transporter sat- 1 in rats exhibits male-dominant gender differences. Pflugers Arch. 2009 Apr;457(6):1381-92.

103 Breljak D, Brzica H, Vrhovac I, Micek V, Karaica D, Ljubojević M, et al. In female rats, ethylene glycol treatment elevates protein expression of hepatic and renal oxalate transporter sat-1 (Slc26a1) without inducing hyperoxaluria. Croat Med J. 2015 Oct;56(5): 447-59.
104 Costa-Bauzá A, Ramis M, Montesinos V, Grases F, Conte A, Pizá P, et al. Type of renal calculi: variation with age and sex. World J Urol. 2007 Aug;25(4):415-21.

105 Markovich D. Slc13a1 and Slc26a1 KO models reveal physiological roles of anion transporters. Physiology (Bethesda). 2012 Feb; 27(1):7-14.

106 Dawson PA, Russell CS, Lee S, McLeay SC, van Dongen JM, Cowley DM, et al. Urolithiasis and hepatotoxicity are linked to the anion transporter Sat1 in mice. J Clin Invest. 2010 Mar;120(3):706-12.

107 Gee HY, Jun I, Braun DA, Lawson JA, Halbritter J, Shril S, et al. Mutations in SLC26A1 cause nephrolithiasis. Am J Hum Genet. 2016 Jun;98(6):1228-34.

108 Hästbacka J, de la Chapelle A, Mahtani MM, Clines G, Reeve-Daly MP, Daly M, et al. The diastrophic dysplasia gene encodes a novel sulfate transporter: positional cloning by fine-structure linkage disequilibrium mapping. Cell. 1994 Sep;78(6):1073-87.

109 Dorwart MR, Shcheynikov N, Yang D, Muallem S. The solute carrier 26 family of proteins in epithelial ion transport. Physiology (Bethesda). 2008 Apr;23(2):104-14.

110 Hästbacka J, Superti-Furga A, Wilcox WR, Rimoin DL, Cohn DH, Lander ES. Sulfate transport in chondrodysplasia. Ann NY Acad Sci. 1996 Jun;785(785):131-6.

111 Markovich D, Aronson PS. Specificity and regulation of renal sulfate transporters. Annu Rev Physiol. 2007;69(1):361-75.

112 Dwyer E, Hyland J, Modaff P, Pauli RM. Genotype-phenotype correlation in DTDST dysplasias: atelosteogenesis type II and diastrophic dysplasia variant in one family. Am J Med Genet A. 2010 Dec;152A(12):304350.

113 Park M, Ohana E, Choi SY, Lee MS, Park JH, Muallem S. Multiple roles of the SO4(2-)/ $\mathrm{Cl}-/ \mathrm{OH}$ - exchanger protein Slc26a2 in chondrocyte functions. J Biol Chem. 2014 Jan; 289(4):1993-2001.

114 Ohana E, Shcheynikov N, Park M, Muallem S. Solute carrier family 26 member a2 (Slc26a2) protein functions as an electroneutral SOFormula/OH-/Cl- exchanger regulated by extracellular Cl-. J Biol Chem. 2012 Feb;287(7):5122-32.

115 Schweinfest CW, Henderson KW, Suster S, Kondoh N, Papas TS. Identification of a colon mucosa gene that is down-regulated in colon adenomas and adenocarcinomas. Proc Natl Acad Sci USA. 1993 May;90(9): 4166-70.

116 Freel RW, Whittamore JM, Hatch M. Transcellular oxalate and $\mathrm{Cl}$ - absorption in mouse intestine is mediated by the DRA anion exchanger Slc26a3, and DRA deletion decreases urinary oxalate. Am J Physiol Gastrointest Liver Physiol. 2013 Oct; 305(7):G520-7.
117 Stenson PD, Mort M, Ball EV, Shaw K, Phillips A, Cooper DN. The Human Gene Mutation Database: building a comprehensive mutation repository for clinical and molecular genetics, diagnostic testing and personalized genomic medicine. Hum Genet. 2014 Jan;133(1):1-9.

118 Schweinfest CW, Spyropoulos DD, Henderson KW, Kim JH, Chapman JM, Barone S, et al. slc26a3 (dra)-deficient mice display chloride-losing diarrhea, enhanced colonic proliferation, and distinct up-regulation of ion transporters in the colon. J Biol Chem. 2006 Dec;281(49):37962-71.

119 Lohi H, Lamprecht G, Markovich D, Heil A, Kujala M, Seidler U, et al. Isoforms of SLC26A6 mediate anion transport and have functional PDZ interaction domains. Am J Physiol Cell Physiol. 2003 Mar;284(3):C76979 .

120 Ohana E, Shcheynikov N, Yang D, So I, Muallem S. Determinants of coupled transport and uncoupled current by the electrogenic SLC26 transporters. J Gen Physiol. $2011 \mathrm{Feb} ; 137(2): 239-51$.

121 Chernova MN, Jiang L, Friedman DJ, Darman RB, Lohi H, Kere J, et al. Functional comparison of mouse slc26a6 anion exchanger with human SLC26A6 polypeptide variants: differences in anion selectivity, regulation, and electrogenicity. J Biol Chem. 2005 Mar:280(9):8564-80.

122 Lohi H, Kujala M, Makela S, Lehtonen E, Kestila M, Saarialho-Kere U, et al. Functional characterization of three novel tissue-specific anion exchangers SLC26A7, -A8, and -A9. J Biol Chem. 2002 Apr;277(16):1424654.

123 Petrovic S, Barone S, Xu J, Conforti L, Ma L, Kujala M, et al. SLC26A7: a basolateral Cl/ $\mathrm{HCO} 3$ cells of the outer medullary collecting duct. Am J Physiol Renal Physiol. 2004; 286(1):F161-9.

124 Marengo SR, Chen DH, Evan AP, Sommer AJ, Stowe NT, Ferguson DG, et al. Continuous infusion of oxalate by minipumps induces calcium oxalate nephrocalcinosis. Urol Res. 2006 Jun;34(3):200-10.

125 Evan AP, Coe FL, Lingeman JE, Shao Y, Sommer AJ, Bledsoe SB, et al. Mechanism of formation of human calcium oxalate renal stones on Randall's plaque. Anat Rec (Hoboken). 2007 Oct;290(10):1315-23.

$126 \mathrm{Xu}$ J, Song P, Nakamura S, Miller M, Barone $\mathrm{S}$, Alper SL. Deletion of the chloride transporter slc26a7 causes distal renal tubular acidosis and impairs gastric acid secretion. J Biol Chem. 2009;284(43):29470-9. 